\title{
Digestion of the zinc in human milk, cow's milk and a commercial babyfood: some implications for human infant nutrition
}

\author{
BY PETER BLAKEBOROUGH AND MICHAEL I. GURR \\ Food Quality and Human Nutrition Department, \\ Food Research Institute, Shinfield, Reading, Berks RG2 9AT \\ AND DALLYN N. SALTER \\ Pig Nutrition and Production Department, Animal and Grassland Research Institute \\ Shinfield, Reading, Berks RG29AQ
}

(Received 24 May 1985 - Accepted 13 September 1985)

\begin{abstract}
1. The digestion of zinc present in human milk, cow's milk and a commercial babyfood was compared, using the piglet as a model for the human infant.

2. In piglets given human milk the $\mathrm{pH}$ of stomach contents was approximately 1 and 0.4 units lower than that of animals given respectively cow's milk and babyfood. The $\mathrm{pH}$ values of intestinal contents were approximately neutral and did not vary with the type of feed.

3. Hard casein curds were present throughout the stomachs and small intestines of animals fed on cow's milk or babyfood and between 55 and $70 \% \mathrm{Zn}$ in these digesta samples were recovered in an insoluble form by centrifugation. In contrast, little solid material was observed in the digesta of animals fed on human milk, and 57 and $93 \%$ respectively of the $\mathrm{Zn}$ in digesta were recovered in a soluble form in the stomach and small intestine.

4. Soluble fractions prepared by centrifugation of digesta were analysed by filtration on Sephadex G-150. After any of the three feeds, soluble $\mathrm{Zn}$ in stomach contents was mainly in a low-molecular-weight form. In intestinal samples, however, $\mathrm{Zn}$ was present in low- and high-molecular-weight forms. Whilst there were similar amounts of $\mathrm{Zn}$ in the low-molecular-weight form in all samples, approximately three times as much of the total intestinal Zn was in a soluble high-molecular-weight form complexed to proteins in the animals fed on human milk compared with those fed on cow's milk or babyfood.

5. Analysis of protein-bound soluble $\mathrm{Zn}$ in intestinal samples on SDS-polyacrylamide gels resulted in a similar pattern of proteins for all feeds. Results indicated that at least some of these proteins were derived from intestinal secretions of the piglet.

6. Some implications of these results in respect of the mode of digestion of $\mathrm{Zn}$ and its biological availability to the human infant are discussed.
\end{abstract}

Zinc in human milk appears to be more efficiently utilized by the human infant than that in cow's milk or commercial babyfoods based on cow's milk. Plasma Zn concentrations of breast-fed infants are significantly higher than those of infants given babyfoods, with or without supplementary Zn (Hambidge et al. 1979). In attempts to explain this observation it has been hypothesized that low-molecular-weight $\mathrm{Zn}$-binding ligands specific to human milk, e.g. citrate (Hurley et al. 1979; Lönnerdal et al. 1980 b) and picolinic acid (Evans \& Johnson, $1980 a, b, c$ ), may facilitate Zn uptake across the small intestine. However, when human and cow's milks were analysed on a column of Sephadex G-150 under non-dissociating conditions, all the $\mathrm{Zn}$ was recovered in forms bound to highmolecular-weight-protein complexes (Blakeborough et al. 1983). In cow's milk, Zn was bound to casein and was not released during the partial dissociation of the micelles. In human milk, $\mathrm{Zn}$ was associated with a protein complex the major component of which was characterized as lactoferrin. In addition, $\mathrm{Zn}$ in intestinal cell cytosol (Cousins et al. 1978) and pancreatic secretions (Lönnerdal et al. $1980 \mathrm{a}$ ) was entirely present in protein-bound forms provided precautions were taken to minimize proteolysis.

We have suggested that the differing high-molecular-weight binders for $\mathrm{Zn}$ in human and sow's milks could provide the primary reason for the lower biological availability of $\mathrm{Zn}$ 
in cow's-milk products to the human infant. It is possible that $\mathrm{Zn}$ could be trapped in poorly digestible casein curds in the gastrointestinal tract of infants given cow's-milk products, and that lactoferrin in human milk could function in the transfer of the metal to the small intestine of the infant (Blakeborough et al. 1983).

To extend these observations we investigated the digestion of $\mathrm{Zn}$ in human milk, cow's milk and a babyfood in the piglet stomach and small intestine. The babyfood chosen, Ostermilk 2 (Glaxo), was based closely on cow's milk and had a high casein content. The piglet was chosen as a model for the human infant because the physiology and metabolism of its gastrointestinal tract is similar to that of the human infant (Clarke \& Hardy, 1971; Moon, 1972; Fransson et al. 1983).

The results reported here indicate that cow's milk and the babyfood were relatively poorly digested by the piglets, much $\mathrm{Zn}$ being trapped in a solid form, whereas human milk was digested so that over $90 \%$ of the $\mathrm{Zn}$ present in the small intestine was recovered in a soluble form.

\section{MATERIALS AND METHODS}

Materials

Piglets were obtained from the Institute piggery. Fresh cow's milk was obtained from the pedigree herd of British Friesian cows maintained at this Institute. Human milk samples were obtained from the John Radcliffe Maternity Hospital, Headington, Oxford. Ostermilk 2 babyfood (Glaxo) was purchased and reconstituted as described by the manufacturer. Chemicals were purchased from Sigma Chemical Co., Poole, Dorset; BDH Chemicals, Poole, Dorset; and Aldrich Chemical Co., Gillingham, Dorset; and were of analytical grade where possible. Sephadex G-150 was purchased from Pharmacia Fine Chemicals, Uppsala, Sweden.

\section{Experimental}

Piglets were given a milk-substitute diet until 14-d-old (Braude \& Newport, 1973). On the day of the experiment the animals received a total of $500 \mathrm{ml}$ human milk, cow's milk or Ostermilk 2 babyfood, in twenty-four equal portions given hourly, after which they were killed. Total digesta were taken from the stomachs and small intestine and examined for appearance and $\mathrm{pH}$. Samples were taken for immediate centrifugation at $8000 \mathrm{~g}$ for $30 \mathrm{~min}$ at room temperature. The resulting supernatant fractions and sediments, together with samples of the original digesta, were stored at $-20^{\circ}$ until required.

\section{Analytical techniques}

Assays. Protein was assayed as described by Lowry et al. (1951), using bovine serum albumin as standard. $\mathrm{Zn}$ was assayed by atomic absorption spectrophotometry, at $213.9 \mathrm{~nm}$, with a Pye Unicam SP 2900 atomic absorption spectrophotometer. The digesta, sediment and supernatant fractions were first solubilized using concentrated sulphuric acid, then diluted with water until the concentration of $\mathrm{H}_{2} \mathrm{SO}_{4}$ was $9 \mathrm{M}$.

Analysis of supernatant fractions on Sephadex G-150. Samples of the supernatant fractions, following centrifugation $(5 \mathrm{ml})$, were analysed on a column of Sephadex G-150 $(500 \mathrm{~mm} \times 25 \mathrm{~mm})$ which was pre-equilibrated with a buffer containing $50 \mathrm{~mm}$-Tris, hydrochloric acid, $3 \mathrm{~mm}$-sodium azide, $\mathrm{pH} \mathrm{7.5}$. The column was eluted using the same buffer. Samples were collected, their absorbance at $280 \mathrm{~nm}$ measured, and analysed for $\mathrm{Zn}$ without solubilizing the samples in $\mathrm{H}_{2} \mathrm{SO}_{4}$.

Calibration of gel-filtration column for molecular weight. The Sephadex G-150 column was calibrated with myoglobin, trypsin inhibitor, ovalbumin, bovine serum albumin and 
Table 1. The pH of digesta samples

(Values are means with their standard errors from the analysis of digesta of six piglets)

\begin{tabular}{llllll}
\hline \hline & \multicolumn{2}{c}{ Stomach $\mathrm{pH}$} & & \multicolumn{2}{c}{ Intestine $\mathrm{pH}$} \\
\cline { 2 - 3 } \cline { 5 - 6 } Feed & Mean & $\mathrm{SE}$ & & Mean & $\mathrm{SE}$ \\
\hline Cow's milk & $3 \cdot 4$ & $0 \cdot 5$ & & $6 \cdot 7$ & $0 \cdot 4$ \\
Human milk & $2 \cdot 3^{*}$ & $0 \cdot 1$ & & $7 \cdot 2$ & $0 \cdot 4$ \\
Babyfood $\dagger$ & $2 \cdot 7 \mathrm{NS}$ & $0 \cdot 3$ & & $7 \cdot 1$ & $0 \cdot 4$ \\
\hline \hline
\end{tabular}

NS, not significant.

Significance of difference between cow's milk and other feeds: ${ }^{*} P<0.05$.

$\dagger$ Ostermilk 2; Glaxo.

$\gamma$-globulins; haemocyanin was used to measure the exclusion volume. A linear relation was obtained between mobility and $\log$ (molecular weight) in the molecular-weight range 16000-155000.

Lactoferrin. Lactoferrin was purified from human milk as described in Blakeborough et al. (1983). It exhibited a single subunit of approximately 75000 molecular weight when analysed by electrophoresis on SDS-polyacrylamide gels (Plate $1(g)$ ).

$S D S$-polyacrylamide gel electrophoresis. Protein samples (1-5 mg) were solubilized in SDS (sodium dodecylsulphate; $10 \mathrm{~g} / 1$ ), and reduced and carboxyamidomethylated as described by Louis \& Shooter (1972). This procedure blocks charged groups on proteins and prevents possible charge effects of proteins on SDS-polyacrylamide gels. Samples were analysed on discontinuous polyacrylamide $(100 \mathrm{~g} / 1)$ disc gels in the buffer system of Ugel et al. (1971). Gels were stained with Coomassie Blue for protein as described by Fairbanks et al. (1971). The molecular weights of the different components of the stained gels were estimated by using calibration proteins of known molecular weight (Louis \& Shooter, 1972), the average from three separate gels providing the calculated figure.

Casein. The identities of casein components present in stained gels were deduced by the method described previously (Blakeborough et al. 1983).

\section{RESULTS}

Many of the results reported here are stated as percentages. These percentages refer to the proportions of the $\mathrm{Zn}$ in the original samples of digesta.

\section{Appearance and $\mathrm{pH}$ of stomach digesta}

In animals given human milk the stomach contents were yellow-white in colour and contained little solid material. Stomach contents of animals given cow's milk and babyfood were also yellow-white but contained hard solid material accounting for much of the volume. The mean $\mathrm{pH}$ values (Table 1) of the stomach contents of piglets fed on human milk were more acidic, by approximately $1 \mathrm{pH}$ unit, than those of piglets receiving cow's milk. Animals given babyfood had stomach $\mathrm{pH}$ values intermediate between those for animals fed on cow's milk and human milk.

\section{Appearance and $p H$ of intestinal digesta}

In animals given human milk the digesta were fluid in consistency; solids were few and dark in colour and were possibly partly derived from ingested faeces. In animals receiving cow's 
Table 2. The distribution of $\mathrm{Zn}(\%$ total $\mathrm{Zn}$ in stomach digesta) between fractions of stomach digesta

(Values are means with their standard errors from analysis of fractions from six piglets except where noted)

\begin{tabular}{|c|c|c|c|c|c|c|}
\hline \multirow[b]{3}{*}{ Feed } & \multicolumn{4}{|c|}{ After centrifugation } & \multicolumn{2}{|c|}{$\begin{array}{l}\text { After analysis of supernatant } \\
\text { fraction on Sephadex G-150 }\end{array}$} \\
\hline & \multicolumn{2}{|c|}{ Pellet } & \multicolumn{2}{|c|}{$\begin{array}{l}\text { Supernatant } \\
\text { fraction }\end{array}$} & \multirow{2}{*}{$\frac{\begin{array}{c}\text { High-molecular- } \\
\text { wt peak }\end{array}}{\text { Mean } \ddagger}$} & \multirow{2}{*}{$\begin{array}{c}\begin{array}{c}\text { Low-molecular- } \\
\text { wt peak }\end{array} \\
\text { Mean } \ddagger\end{array}$} \\
\hline & Mean & $\mathrm{SE}$ & Mean & SE & & \\
\hline Cow's milk & $71 \cdot 3$ & 8.4 & $28 \cdot 7$ & 8.4 & $3 \cdot 4$ & $25 \cdot 4$ \\
\hline Human milk & $42.6^{*}$ & $10 \cdot 7$ & $57 \cdot 4^{*}$ & $10 \cdot 7$ & $20 \cdot 2$ & 37.3 \\
\hline Babyfood $\uparrow$ & $55.4 \mathrm{NS}$ & $4 \cdot 7$ & $44 \cdot 6 \mathrm{NS}$ & 4.7 & $2 \cdot 4$ & $42 \cdot 2$ \\
\hline
\end{tabular}

NS, not significant.

Significance of difference between cow's milk and other feeds: ${ }^{*} P<0.05$

$\dagger$ Ostermilk 2; Glaxo.

$\ddagger$ Means of two results.

Table 3. The distribution of $\mathrm{Zn}(\%$ total $\mathrm{Zn}$ in intestinal digesta) between fractions of intestinal digesta

(Values are means with their standard errors from analysis of fractions from six piglets)

\begin{tabular}{|c|c|c|c|c|c|c|c|c|}
\hline \multirow[b]{3}{*}{ Feed } & \multicolumn{4}{|c|}{ After centrifugation } & \multicolumn{4}{|c|}{$\begin{array}{l}\text { After analysis of supernatant fraction } \\
\text { on Sephadex G-150 }\end{array}$} \\
\hline & \multicolumn{2}{|c|}{ Pellet } & \multicolumn{2}{|c|}{$\begin{array}{l}\text { Supernatant } \\
\text { fraction }\end{array}$} & \multicolumn{2}{|c|}{$\begin{array}{l}\text { High-molecular- } \\
\text { wt peak }\end{array}$} & \multicolumn{2}{|c|}{$\begin{array}{l}\text { Low-molecular- } \\
\text { wt peak }\end{array}$} \\
\hline & Mean & $\mathbf{S E}$ & Mean & SE & Mean & SE & Mean & $\mathrm{SE}$ \\
\hline Cow's milk & $60 \cdot 1$ & $13 \cdot 0$ & $39 \cdot 9$ & $13 \cdot 0$ & $25 \cdot 0$ & 6.5 & $14 \cdot 9$ & $6 \cdot 5$ \\
\hline Human milk & $6 \cdot 9^{* *}$ & $5 \cdot 1$ & $93 \cdot 1 * *$ & $5 \cdot 1$ & $70 \cdot 5^{*}$ & $11 \cdot 1$ & $22 \cdot 6 \mathrm{NS}$ & $11 \cdot 1$ \\
\hline Babyfood $\uparrow$ & $66 \cdot 1 \mathrm{NS}$ & $12 \cdot 6$ & $33.9 \mathrm{NS}$ & $12 \cdot 6$ & $13.8 \mathrm{NS}$ & $1 \cdot 3$ & $20 \cdot 1 \mathrm{NS}$ & $1 \cdot 3$ \\
\hline
\end{tabular}

NS, not significant.

Significance of difference between cow's milk and other feeds: ${ }^{*} P<0.05,{ }^{* *} P<0.005$.

$\dagger$ Ostermilk 2; Glaxo.

milk and babyfood the digesta were semi-solid in consistency and contained white solid material throughout the length of the intestines. Before fractionation, samples were bright orange in colour, presumably due to bile secretions. All digesta samples from 14-d-old piglets were of similar $\mathrm{pH}$ and were approximately neutral (Table 1 ).

\section{Distribution of $\mathrm{Zn}$ between fractions of digesta}

After centrifuging the stomach contents of 14-d-old animals fed on human milk, an average of $43 \%$ of total $\mathrm{Zn}$ was recovered in the sediment. A similar analysis of samples from animals given cow's milk demonstrated an approximate twofold percentage increase of $\mathrm{Zn}$ in the sediment. Animals given babyfood had values for sedimentable $\mathrm{Zn}$ which were intermediate between those for animals fed on human milk and cow's milk (Table 2). Over 93\% of the 

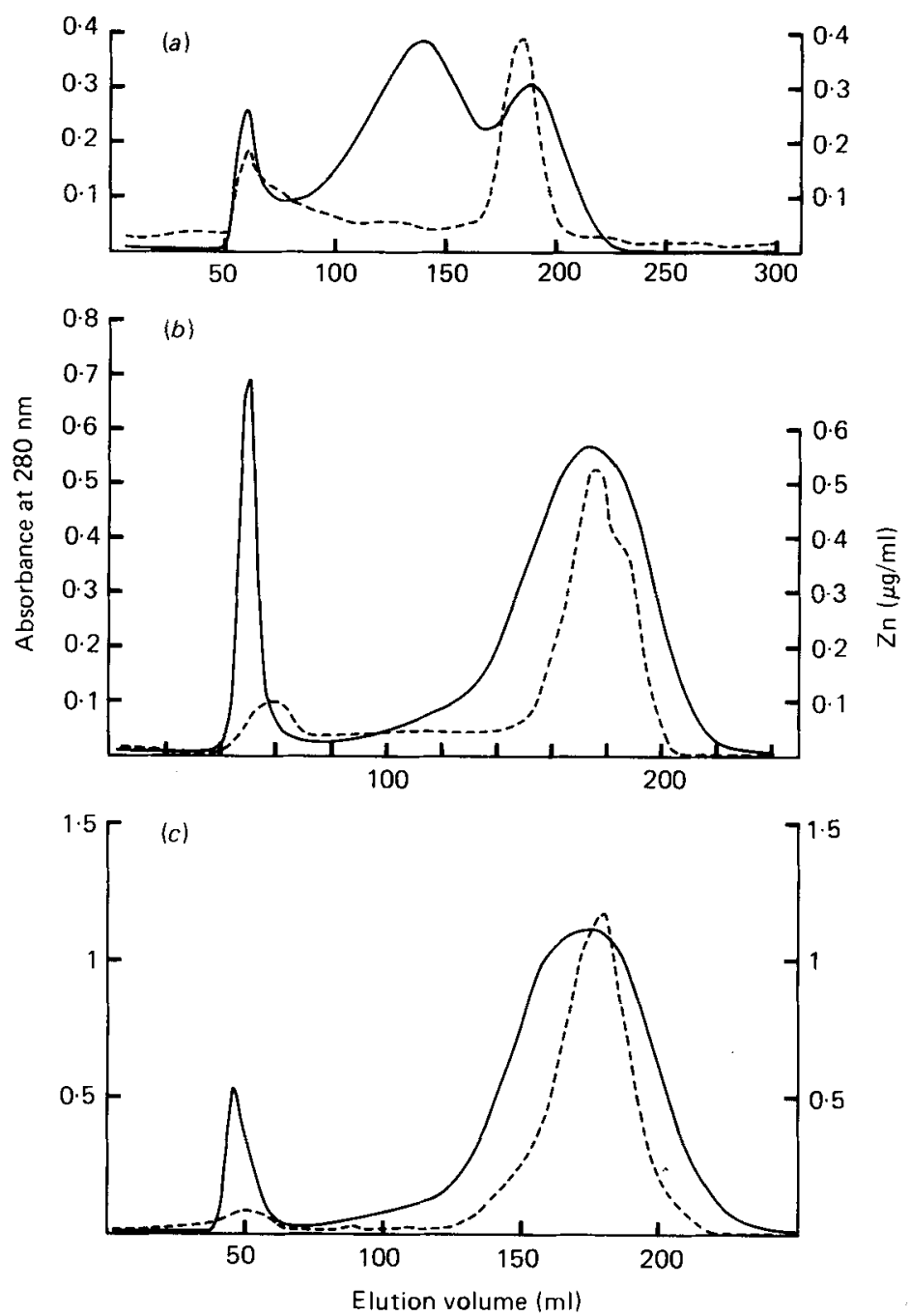

Fig. 1. Analysis of stomach digesta on Sephadex G-150. Piglets (14-d-old) were fed on (a) human milk, (b) cow's milk or (c) Ostermilk 2 babyfood (Glaxo) for $24 \mathrm{~h}$. The animals were killed and digesta removed from their stomachs and centrifuged. Samples of the resulting supernatant fractions $(5 \mathrm{ml})$ were analysed on a column of Sephadex G-150 $(500 \mathrm{~mm} \times 25 \mathrm{~mm})$. The eluting buffer was $50 \mathrm{~mm}$-Tris-hydrochloric acid-3 mM-sodium azide, $\mathrm{pH} 7 \cdot 5$. Fractions were collected from piglets fed on human milk ( $5 \mathrm{ml})$, cow's milk $(2 \mathrm{ml})$ and babyfood $(2 \mathrm{ml})$. Fractions were monitored by measuring absorbance at $280 \mathrm{~nm}(-)$ and analysed by atomic absorption spectrophotometry for $\mathrm{Zn}(----)$.

$\mathrm{Zn}$ was recovered in the supernatant fractions after centrifuging the intestinal digesta of animals given human milk. In animals receiving cow's milk and babyfood, over $60 \%$ of the $\mathrm{Zn}$ was still associated with solid material and was sedimented (Table 3).

\section{Analysis of supernatant fractions on Sephadex G-150}

In all samples, $\mathrm{Zn}$ was quantitatively recovered in two peaks from Sephadex G-150. A high-molecular-weight peak emerged at the exclusion volume of the column and had a molecular weight of $>150000$. A low-molecular-weight peak was eluted after a column- 

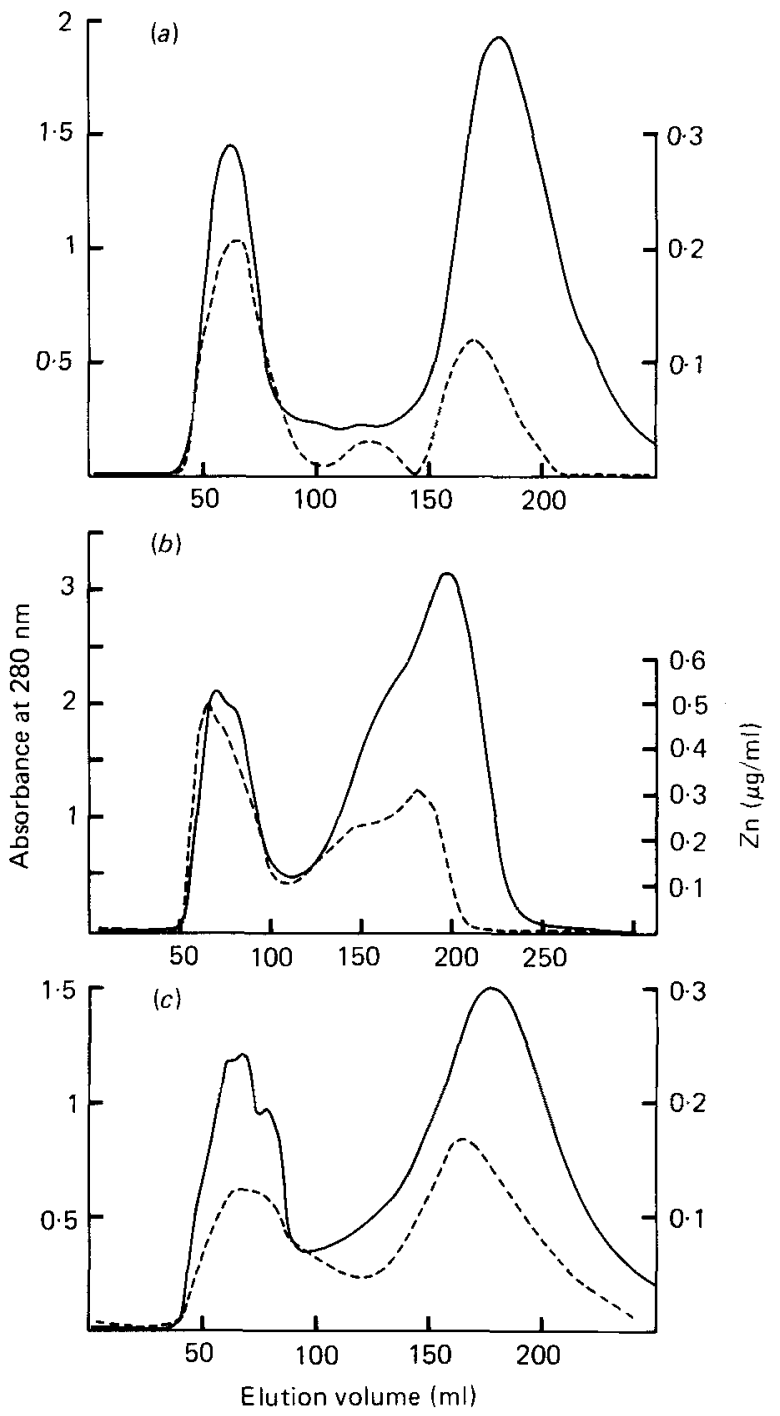

Fig. 2. Analysis of intestinal digesta on Sephadex G-150. Piglets (14-d-old) were fed on (a) human milk, (b) cow's milk or (c) Ostermilk 2 babyfood (Glaxo) for $24 \mathrm{~h}$. The animals were killed and digesta removed from their small intestines and centrifuged. Samples of the resulting supernatant fractions $(5 \mathrm{ml})$ were analysed on a column of Sephadex G-150 $(500 \mathrm{~mm} \times 25 \mathrm{~mm})$. The eluting buffer was $50 \mathrm{~mm}$-Trishydrochloric acid-3 mM-sodium azide, $\mathrm{pH} 7 \cdot 5$. Fractions were collected from piglets fed on human milk $(2 \mathrm{ml})$, babyfood $(2 \mathrm{ml})$ and cow's milk $(5 \mathrm{ml})$. Fractions were monitored by measuring their absorbance at $280 \mathrm{~nm} \mathrm{(-)} \mathrm{and} \mathrm{analysed} \mathrm{by} \mathrm{atomic} \mathrm{absorption} \mathrm{spectrophotometry} \mathrm{for} \mathrm{Zn} \mathrm{(---)}$.

volume of buffer had passed through, and had a molecular weight of $<5000$ (Figs. 1 and 2). The proportion of $\mathrm{Zn}$ in the high-molecular-weight peak was variable between the stomach samples. However, a considerable amount of $\mathrm{Zn}$ was recovered in the lowmolecular-weight peaks (Table 2, Fig. 1) and all three feeds produced similar percentages of stomach $\mathrm{Zn}$ in these fractions.

In the intestinal samples, low-molecular-weight $\mathrm{Zn}$ was present as similar percentages in all samples. The percentage of total intestinal $\mathrm{Zn}$ present in the high-molecular-weight form 
in piglets given human milk was approximately three times that in animals given cow's milk or babyfood (Table 3, Fig. 2).

\section{Analysis of high-molecular-weight fractions of intesinal supernatant fractions by SDS-polyacrylamide gel electrophoresis}

The analysis of the high-molecular-weight fractions, prepared by filtration of intestinal samples on Sephadex G-150, on SDS-polyacrylamide gels, is illustrated in Plate 1. Samples from animals given human milk, cow's milk and babyfood gave rise to similar patterns of proteins. Five components were observed in all samples. These had molecular weights of approximately $96000,86000,73000,50000$ and 27000 . Minor protein components differed in the samples. The 73000-molecular-weight protein corresponded in mobility to lactoferrin (cf. Plate $1(\mathrm{~g})$ ). It was very much reduced in concentration in the intestines of animals given human milk as compared with human milk itself but was relatively increased in the intestinal contents of animals given cow's milk or babyfood. The 86000- and 50000-molecularweight components did not correspond in mobility with any proteins observed in either of the milks or the babyfood. Proteins with molecular weights corresponding to casein were virtually absent from the soluble fractions of all intestinal samples (cf. Plate 1(a), $(c)$ ).

\section{DISCUSSION}

The method of centrifuging digesta at low speed produced two fractions, both containing $\mathrm{Zn}$. The pellet fractions consisted of solid material, indicative of poor digestion. The supernatant fractions contained material in solution produced by digestion, which would be potentially available to the absorptive processes of the animal.

The observed distribution of $\mathrm{Zn}$ between insoluble and soluble fractions and between highand low-molecular-weight species in the digesta indicated that the courses of digestion of cow's milk and the babyfood were similar in the piglet. However, there were marked differences in the distribution of $\mathrm{Zn}$ in the components of the digesta when human milk was given, that could clearly have a significant effect on $\mathrm{Zn}$ availability. Even from a brief visual examination of the digesta it was apparent that much white solid material (casein curds) was present in the stomach and even throughout the length of the small intestine of animals given cow's milk or babyfood, but not in those given human milk. Furthermore, much of the $\mathrm{Zn}$ was sequestered in these hard curds $(55-72 \%$ of total stomach or intestinal $\mathrm{Zn}$ ) from animals given cow's milk and babyfood whereas $57-93 \%$ of $\mathrm{Zn}$ was in a soluble form in the gastrointestinal tract of piglets given human milk. In addition, digestion of human milk in the stomach was more efficient, as shown by the more acidic $\mathrm{pH}$ there, compared with animals fed on cow's milk or babyfood. $\mathrm{Zn}$ is known to be bound to proteins in cow's and human milks (Blakeborough et al. 1983). Analysis of stomach soluble (supernatant fraction) $\mathrm{Zn}$ on Sephadex G-150 showed that a significant amount of the metal was stripped from its protein binders and was present in a low-molecular-weight form $(<5000)$ not complexed to protein.

All intestinal samples contained relatively more $\mathrm{Zn}$ in a protein-complexed form than was observed in the stomach. Approximately three times the relative amount of soluble high-molecular-weight $\mathrm{Zn}$ was observed in animals given human milk as compared with those fed on cow's milk or babyfood. All three feeds gave rise to a similar pattern of $\mathrm{Zn}$-binding intestinal protein components on SDS-polyacrylamide gels. Several of these proteins were not observed in the original feeds and it appears that the $\mathrm{Zn}$-binding protein complex of the piglet intestine is, at least in part, derived from intestinal secretions. Alternatively, these proteins could be formed as the result of intestinal proteolytic digestion of higher molecular-weight milk proteins. Low-molecular-weight $\mathrm{Zn}$ which was not bound 
to protein components was present in similar relative amounts irrespective of which of the three feeds was given to the piglets.

Intestinal digestion of $\mathrm{Zn}$ in human milk, cow's milk and Ostermilk 2 babyfood appears therefore to follow the same course in each case in the piglet. The metal is stripped from its milk-protein binders in the acid conditions of the stomach. In the intestine $\mathrm{Zn}$ then recombines with a protein complex, but some $\mathrm{Zn}$ remains uncomplexed in a low-molecularweight form. The suggestion that human milk contains a specific low-molecular-weight $\mathrm{Zn}$-binding compound, not present in cow's milk, that renders $\mathrm{Zn}$ more available to the human infant by enhancing $\mathrm{Zn}$ uptake across the small intestine (Eckhert et al. 1977; Hurley et al. 1977; Lönnerdal et al. 1980 b) is therefore not supported by these results.

Our results suggest that the following mechanism may occur. $\mathrm{Zn}$ in cow's milk and babyfoods closely based on cow's milk is all complexed to casein micelles (Parkash \& Jenness, 1967; Blakeborough et al. 1983). When cow's milk and babyfood casein is subjected to mild digestive conditions, e.g. in the piglet and human infant, it forms hard curds that trap $\mathrm{Zn}$ in a solid form which, because these persist throughout the length of the small intestine, will render much of the $\mathrm{Zn}$ unavailable to the infant. In contrast, $\mathrm{Zn}$ in human milk is digested so that almost all of it is in solution in the small intestine and is thus potentially available for absorption. In this way human milk, which contains less $\mathrm{Zn}$ than cow's milk, may actually donate more $\mathrm{Zn}$ to the infant.

Our results are less indicative of the possible role of lactoferrin in $\mathrm{Zn}$ uptake. The observed decrease in concentration of a protein of similar molecular weight to lactoferrin in the intestinal digesta of animals given human milk as compared with human milk itself does not argue for a role in facilitating $\mathrm{Zn}$ uptake. However, lactoferrin is known to bind to the mucosal surfaces of the human small intestine (Masson et al. 1969) and it is possible that it may exert a physiological effect on $\mathrm{Zn}$ uptake there. It would be interesting to investigate this possibility using in vitro systems.

Regarding infant nutrition, our results indicate that the $\mathrm{Zn}$ content of babyfoods is not necessarily a measure of $\mathrm{Zn}$ biological availability and that $\mathrm{Zn}$-binding compounds present in the food must be taken into account. Human milk is clearly to be recommended as the better source of biologically available $\mathrm{Zn}$ for the human infant. In cases where babyfoods are unavoidable, consideration should be given to those with a low casein content and a higher concentration of whey proteins.

The authors are pleased to acknowledge the technical assistance of Ms Sheila Neville during these studies. They are grateful to Dr Michael J. Newport for the provision of facilities and expertise during the handling of the piglets. Human milk samples were donated by the Maternity Department, The John Radcliffe Hospital, Headington, Oxford, with the kind cooperation of Dr A. Williams and his staff.

\section{REFERENCES}

Blakeborough, P., Salter, D. N. \& Gurr, M. I. (1983). Biochemical Journal 209, 505-512.

Braude, R. \& Newport, M. J. (1973). British Journal of Nutrition 29, 447-455.

Clarke, R. M. \& Hardy, R. N. (1971). Journal of Anatomy 108, 63-77.

Cousins, R. J., Smith, K. T., Failla, M. L. \& Markowitz, L. A. (1978). Life Sciences 23, 1819-1826.

Eckhert, C. D., Sloan, M. V., Duncan, J. R. \& Hurley, L. S. (1977). Science 195, 789-790.

Evans, G. W. \& Johnson, E. C. (1980a). Journal of Nutrition 110, 1076-1080.

Evans, G. W. \& Johnson, E. C. (1980 b). Proceedings of the Society for Experimental Biology and Medicine 165, $457-461$.

Evans, G. W. \& Johnson, P. E. (1980c). Pediatric Research 14, 876-880.

Fairbanks, G., Steck, T. L. \& Wallach, D. F. H. (1971). Biochemistry 10, 2606-2616.

Fransson, G.-B., Thorén-Tolling, K., Jones, B., Hambraeus, L. \& Lönnerdal, B. (1983). Nutrition Research 3, 373-384. 


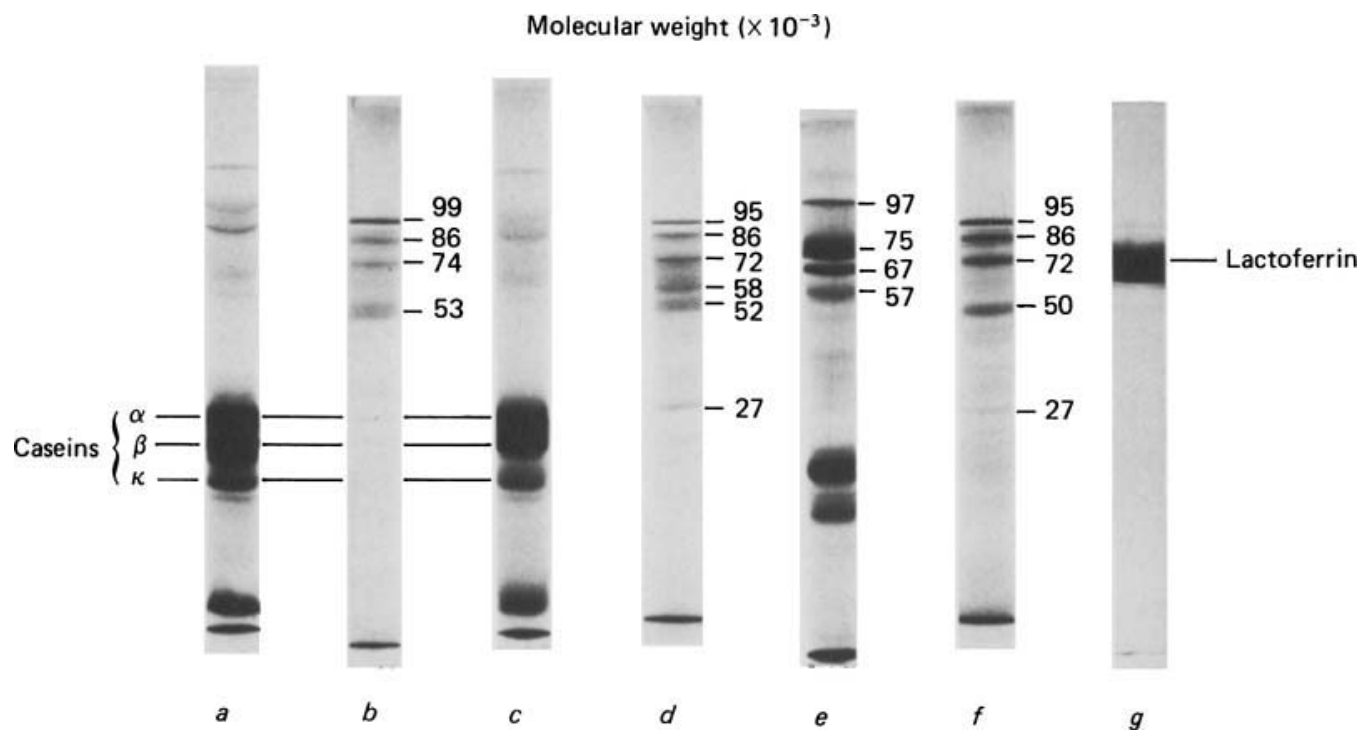


Hambidge, K. M., Walravens, P. A., Casey, C. E., Brown, R. M. \& Bender, C. (1979). Journal of Pediatrics 94 , $607-608$.

Hurley, L. S., Duncan, J. R., Sloan, M. V. \& Eckhert, C. D. (1977). Proceedings of the National Academy of Sciences (USA) 74, 3547-3549.

Hurley, L. S., Lönnerdal, B. \& Stanislowski, A. G. (1979). Lancet i, 677-678.

Lönnerdal, B., Schneeman, B. O., Keen, C. L. \& Hurley, L. S. (1980a). Biological Trace Element Research 2 , 149-158.

Lönnerdal, B., Stanislowski, A. G. \& Hurley, L. S. (1980 b). Journal of Inorganic Biochemistry 12, 71-78.

Louis, C. F. \& Shooter, E. M. (1972). Archives of Biochemistry and Biophysics 153, 641-655.

Lowry, O. H., Rosebrough, N. J., Farr, A. L. \& Randall, R. J. (1951). Journal of Biological Chemistry 193, 265-275.

Masson, P. L., Heremans, J. F., Schonne, E. \& Crabbe, P. A. (1969). Protides of Biological Fluids Proceedings Colloquium 16, 633-638.

Moon, H. W. (1972). Veterinary Pathology 9, 3-21.

Parkash, S. \& Jenness, R. (1967). Journal of Dairy Science 50, 127-134.

Ugel, A. R., Chrambach, A. \& Rodbard, D. (1971). Analytical Biochemistry 43, 410-426.

\section{EXPLANATION OF PLATE}

Plate 1. Analyses of milks and the high-molecular-weight $\mathrm{Zn}$ fractions prepared by filtration of centrifugation supernatant fractions of intestinal digesta samples on Sephadex G-150, by SDS-polyacrylamide gel electrophoresis. Samples of $(a)$ cow's milk, $(b)$ intestinal high-molecular-weight $\mathrm{Zn}$ peak of piglets given cow's milk, $(c)$ Ostermilk 2 babyfood (Glaxo), (d) intestinal high-molecular-weight $\mathrm{Zn}$ peak of animals given babyfood, (e) human milk, $(f)$ intestinal high-molecular-weight $\mathrm{Zn}$ peak of animals given human milk, $(g)$ human milk lactoferrin were reduced and carboxyamidomethylated, and analysed on SDS-polyacrylamide disc gels (for details, see p. 211). The gels were stained with Coomassie Blue for protein. 